Jurnal Nutrisia

Vol.22, No.1(Maret) 2020, pp. 32 - 38

E-ISSN: 2614-7165, P- ISSN 1693-945X

DOI 10.29238/jnutri.v22i1.197

Journal homepage: http:// www.nutrisiajournal.com

\title{
Edukasi Kelompok Sebaya sebagai Pencegahan Anemia Gizi Besi pada Remaja
}

\section{Rini Wuri Astuti ${ }^{1}$, Isti Suryani ${ }^{2}$}

${ }^{1}$ Jurusan Gizi Poltekkes Kemenkes Yogyakarta, Jalan Tata Bumi No.3, Banyuraden, Kec. Gamping, Kab. Sleman Prop. D.I.Yogyakarta-Indonesia 55293, riniwuri@yahoo.com

${ }^{2}$ Jurusan Gizi Poltekkes Kemenkes Yogyakarta , Jalan Tata Bumi No.3, Banyuraden, Kec. Gamping, Kab. SlemanProp . D.I.Yogyakarta-Indonesia 55293

\begin{abstract}
Kata kunci: $\quad$ ABSTRAK
Edukasi $\quad$ Latar belakang : Anemia Gizi besi (AGB) merupakan salah satu masalah gizi yang kelompok banyak dijumpai di Indonesia khususnya pada remaja. Remaja putri beresiko tinggi sebaya mengalami anemia. Pencegahan anemia gizi besi pada remaja dapat dilakukan melalui pemberdayaan masyarakat melalui edukasi pada kelompok sebaya. Tujuan Khusus : Pengetahuan Mengetahui pengaruh pemberdayaan masyarakat melalui edukasi kelompok sebaya dan sikap terhadap pengetahuan dan sikap pencegahan anemia gizi besi pada remaja. Metode Penelitian : Penelitian ini merupakan penelitian quacy experimental dengan rancangan Anemia gizi pre-post test with control group design. Penelitian ini bertempat di Desa Trimurti, besi. Srandakan, Bantul. Populasi dalam penelitian adalah seluruh remaja putri. Analisis bivariat menggunakan uji Independent Sample T-Test dan uji Mann Whitney. Hasil : Ada peningkatan pengetahuan secara signifikan sebelum dan setelah intervensi edukasi kelompok sebaya pada kelompok perlakuan $p=0,001(p<0,05)$, dan kelompok kontrol $\mathrm{p}=0,037$ ( $\mathrm{p}<0,05)$. Nilai sikap sebelum dan setelah intervensi pada kelompok perlakuan berubah positif secara signifikan dengan nilai $p=0,002(p<0,05)$. Nilai sikap sebelum dan setelah intervensi pada kelompok kontrol berubah secara positif tetapi tidak signifikan dengan $p=0,46 \quad(p>0,05)$. Kesimpulan: Intervensi edukasi kelompok sebaya meningkatkan pengetahuan dan sikap anemia gizi besi secara signifikan. ABSTRACT

Key word: $\quad$ Background: Iron Deficiency Anemia is a nutritional problem that is often found in Indonesia peer group education especially among adolescents (fertile age group). Young women have the highest risk of developing anemia. Prevention of iron nutrition anemia in adolescents through peer group approaches is expected to provide optimal results, because peer groups develop discussion, knowledge and sharing and education activities, as well as dynamic processes in groups. Specific Objectives: attitudes To determine the effect of community empowerment through peer group education on knowledge and attitudes to prevent iron nutrition anemia in adolescents. Method: This study is a quacy iron deficiency experimental study with a pre-post test design with control group design. The research was anemia conducted in the period August to November 2019 at Trimurti Village, Srandakan, Bantul. The population in this study were all young women. Bivariate analysis using the Independent Sample T-Test and the Mann Whitney test. Results: There was a significant increase in knowledge before and after the peer education intervention in the treatment group $p=0.001(p<0.05)$, and the control group $p=0.037(p<0.05)$. The attitude value before and after the intervention in the treatment group significantly changed positively with a value of $p=0.002(p<0.05)$. The attitude value before and after intervention in the control group changed positively but not significantly with $p=0.46$ ( $p>0.05)$. Conclusion: Peer education intervention significantly increased knowledge and attitude of iron nutrition anemia.
\end{abstract}

This is an open access article under the CC-BY-SA license. 


\section{Pendahuluan}

Anemia Gizi besi (AGB) merupakan salah satu masalah gizi yang banyak dijumpai di Indonesia khususnya pada kelompok remaja. Anemia menduduki urutan ke-4 dari 10 kelompok penyakit terbanyak di Indonesia.[1] Berdasarkan data WHO (2013), prevalensi anemia dunia berkisar 40-88\%. Hasil Riset Kesehatan Dasar tahun 2018, proporsi anemia pada ibu hamil terjadi peningkatan dari tahun 2013 yaitu sebesar 37,1\% menjadi 48,9\% pada tahun 2018, yang mana 84,6\% berusia 15-24 tahun.[2] [3] Remaja putri mempunyai resiko mengalami anemia paling tinggi.[4] Di Indonesia, jumlah penduduk usia remaja yaitu rentang 10-19 tahun sebesar 26,2\% yang terdiri dari 49,1\% perempuan dan 50,9\% laki-laki.[3]

Masalah Gizi dipengaruhi oleh beberapa faktor yang saling berkaitan baik secara langsung maupun tidak. Secara langsung dipengaruhi oleh kurangnya asupan zat gizi baik kualitas maupun kuantitas dan adanya penyakit infeksi. Sedangkan secara tidak langsung dipengaruhi oleh pola asuh keluarga, ketahanan pangan yang rendah, kondisi sanitasi lingkungan, serta kualitas dan jangkauan layanan kesehatan.[5] [6] Pokok masalahnya adalah tingkat pendapatan masyarakat, rendahnya pendidikan, pengetahuan, dan ketrampilan, sehingga untuk mengatasi diperlukan penanganan yang sinergis, terintegrasi, serta memerlukan dukungan masyarakat, swasta, LSM, dan lintas sektor lainnya.[5] [6]

Perbaikan pencegahan anemia gizi besi dan kurang gizi pada masa remaja sangat diperlukan untuk mencegah kurang gizi pada ibu hamil serta generasi selanjutnya. Menurut Depkes (2008), strategi operasional penanggulangan anemia gizi pada remaja dijabarkan dalam 2 kegiatan utama yaitu suplementasi tablet tambah darah (TTD) dan komunikasi, informasi, dan edukasi (KIE). Upaya pencegahan dan penanggulangan anemia melalui suplementasi TTD sangat bergantung dengan program pemerintah.

Pencegahan anemia gizi pada remaja tidak akan berhasil jika hanya dilakukan oleh pemerintah tanpa dukungan seluruh lintas sektor baik dari masyarakat, organisasi masyarakat, maupun swasta lainnya. Keberhasilan program pencegahan dan penanggulangan perlu dukungan penuh dari seluruh lapisan masyarakat untuk berperan aktif sebagai subyek maupun obyek. Upaya perbaikan gizi sebaiknya dilakukan oleh, dari dan untuk masyarakat, sehingga perlu diupayakan pemberdayaannya.

Upaya pencegahan anemia gizi besi pada remaja melalui pendekatan kelompok sebaya diharapkan dapat memberikan hasil yang lebih optimal, karena melalui kelompok sebaya berkembang kegiatan diskusi, sharing, dan edukasi, serta terjadi proses yang dinamis dalam kelompok. Model intervensi melalui kelompok sebaya perlu dikembangkan dan diharapkan lebih efektif dan efisien dalam meningkatkan pengetahuan dan sikap masyarakat khususnya remaja dalam pencegahan anemia gizi besi. Penelitian ini bertujuan mengetahui pengaruh pemberdayaan masyarakat melalui edukasi kelompok sebaya terhadap pengetahuan dan sikap pencegahan anemia gizi besi pada remaja.

\section{Metode}

Penelitian ini merupakan penelitian quacy experimental dengan rancangan pre-post test with control group design. Rancangan penelitian menggunakan dua kelompok, yaitu kelompok 
kontrol dan kelompok perlakuan yang masing-masing diukur variabelnya sebelum dan sesudah perlakuan. Penelitian dilakukan pada periode Agustus s.d November 2019.

Populasi dalam penelitian ini adalah remaja putri di Desa Trimurti, Kecamatan Srandakan, Kabupaten Bantul, Yogyakarta. Dari dusun di Desa Trimurti, diambil 1 dusun sebagai kelompok perlakuan dan 1 dusun sebagai kelompok intervensi. Sampel penelitian dalam setiap kelompok yaitu 42 orang dalam kelompok perlakuan dan 42 orang dalam kelompok kontrol. Kriteria inklusi penelitian adalah remaja aktif dalam organisasi Karang Taruna, berusia 17-35 tahun, berdomisili di dusun perlakuan dan dusun kontrol, serta bersedia menjadi responden.

Variabel bebas dalam penelitian ini terdiri dari edukasi kelompok sebaya sedangkan variabel terikatnya adalah pengetahuan dan sikap pencegahan anemia gizi besi. Instrumen yang digunakan Informed consent, formulir karakteristik, kuesioner pengetahuan, kuesioner sikap, buklet. Duta gizi remaja melakukan intervensi edukasi tentang pencegahan anemia gizi besi pada remaja di dalam kelompok sebaya menggunakan media booklet, kartu bahan makanan, dan bahan makanan asli.

Analisis data dilakukan secara univariat dan bivariat. Analisis univariat dilakukan untuk mendeskripsikan data gambaran karakteristik subjek. Analisis bivariat menggunakan Uji Independent Sample T-Test dan uji Mann Whitney.

\section{Hasil Dan Pembahasan}

\subsection{Pelatihan Pencegahan Anemia Gizi Besi Remaja}

Pemberdayaan merupakan upaya untuk menumbuhkan dan meningkatkan pengetahuan, kemauan, dan kemampuan remaja untuk mencegah anemia, meningkatkan kesehatannya, menciptakan lingkungan sehat serta berperan aktif dalam setiap upaya penaggulangan anemia di daerahnya.[1] Tahap awal pelaksanaan kegiatan pemberdayaan masyarakat dimulai dengan mengidentifikasi masalah (feel needs) dan sumber daya. Kemudian dilaksanakan pelatihan yang dihadiri oleh perwakilan remaja dari masing-masing dusun di Desa Trimurti, petugas Puskesmas, dan kelurahan.

Kegiatan dilanjutkan dengan pemilihan duta gizi remaja. Dengan adanya duta gizi ini, diharapkan dapat menyampaikan promosi gizi mengenai pencegahan anemia gizi besi remaja untuk menguatkan pengetahuan dan praktik gizi pada remaja di daerahnya.

\subsection{Karakteristik Subjek Penelitian}

Berdasarkan hasil penelitian, didapatkan karakteristik responden menurut umur dan pendidikan yang disajikan pada Tabel 1 .

Tabel 1.Distribusi Responden menurut Umur

\begin{tabular}{cccc}
\hline Variabel & Kelompok & Mean & SD \\
\hline \multirow{2}{*}{ Umur } & Perlakuan & 18,71 & 2,201 \\
\cline { 2 - 4 } & Kontrol & 19,79 & 3,324 \\
\hline
\end{tabular}

Tabel 1. menunjukkan rata-rata umur responden pada kelompok perlakuan dan kelompok kontrol hampir sama masing-masing 18,71 tahun $( \pm 2,20)$ dan 19,79 tahun $( \pm 3,324)$. 
Tabel 2. Karakteristik Pendidikan Responden

\begin{tabular}{|c|c|c|c|c|c|}
\hline \multicolumn{2}{|c|}{ Karakteristik } & \multicolumn{4}{|c|}{ Total } \\
\hline & & \multicolumn{2}{|c|}{ Perlakuan } & \multicolumn{2}{|c|}{ Kontrol } \\
\hline & & $\mathrm{n}$ & $\%$ & $\mathrm{n}$ & $\%$ \\
\hline \multirow[t]{6}{*}{ Pendidikan } & SD & 0 & 0 & 2 & 4,8 \\
\hline & SMP & 16 & 38,1 & 11 & 26,2 \\
\hline & SMA & 25 & 59,5 & 24 & 57,1 \\
\hline & Diploma & 0 & 0 & 1 & 2,4 \\
\hline & Sarjana & 1 & 2,4 & 4 & 9,5 \\
\hline & umlah & 42 & 100 & 42 & 100 \\
\hline
\end{tabular}

Berdasarkan Tabel 2., proporsi pendidikan responden hampir sama antara kelompok perlakuan dan kelompok kontrol. Proporsi pendidikan terbesar dari seluruh responden adalah SMA 58,3\% dan SMP 32,2 \%.

\subsection{Perbedaan pengetahuan, sikap dalam pencegahan anemia gizi besi sebelum dan setelah intervensi}

Hasil analisis perbedaan rata-rata nilai pengetahuan, sikap, sebelum dan setelah intervensi pada kedua kelompok dapat dilihat pada Tabel 3.

Tabel 3.Analisis Perbedaan Rata-Rata Pengetahuan, Sikap Remaja dalam Pencegahan Anemia Gizi Besi sebelum dan setelah Intervensi pada Kelompok Perlakuan dan Kontrol

\begin{tabular}{clcccc}
\hline Variabel & \multicolumn{1}{c}{ Kelompok } & Mean & SD & Nilai t & Nilai p \\
\hline \multirow{5}{*}{ Pengetahuan } & Perlakuan & & & & \\
& - Sebelum & 85,12 & 8,29 & - & 0,001 \\
\cline { 2 - 6 } & - Setelah & 95,71 & 4,49 & & \\
\cline { 2 - 6 } & Kontrol & & & & \\
& - Sebelum & 78,45 & 14,67 & - & 0,037 \\
& - Setelah & 82,98 & 11,05 & & \\
\hline \multirow{5}{*}{ Sikap } & Perlakuan & & & & \\
& - Sebelum & 61,91 & 4,30 & $-3,311$ & 0,002 \\
& - Setelah & 65,12 & 4,59 & & \\
\cline { 2 - 6 } & Kontrol & & & & \\
& - Sebelum & 63,55 & 5,82 & $-0,746$ & 0,460 \\
& - Setelah & 65,59 & 5,57 & & \\
\hline
\end{tabular}

Berdasarkan Tabel 3. diperoleh data bahwa terdapat peningkatan pengetahuan baik pada kelompok perlakuan maupun kontrol pada saat sebelum dibandingkan dengan setelah intervensi, akan tetapi pada kelompok perlakuan yang mendapat intervensi edukasi kelompok sebaya diperoleh nilai rata-rata yang lebih tinggi. Hal ini sejalan dengan penelitian Sulistyowati yang didapatkan hasil, ada peningkatan pengetahuan remaja putri setelah pemberian intervensi pendidikan kesehatan tentang anemia $(p=0,000)$.[8] Hasil ini serupa dengan yang ditunjukkan pada penelitian lain bahwa ada manfaat pendidikan gizi terhadap peningkatan pengetahuan setelah diberikan penyuluhan atau pendidikan.[9] [10] 
Hasil analisis dengan uji Wilcoxon didapatkan hasil pengetahuan sebelum dan setelah intervensi pada kelompok perlakuan dan kelompok kontrol meningkat secara signifikan dengan signifikansi pada kelompok perlakuan $\mathrm{p}=0,001(\mathrm{p}<0,05)$, dan kelompok kontrol $\mathrm{p}=0,037$ $(p<0,05)$. Peningkatan pengetahuan terjadi karena intervensi edukasi diberikan kepada kedua kelompok, untuk kelompok kontrol edukasi hanya dilakukan dengan media buklet sedangkan kelompok perlakuan melalui peran edukasi kelompok sebaya. Setelah ditelusuri lebih lanjut peningkatan pengetahuan yang lebih tinggi pada kelompok perlakuan terjadi pada item pertanyaan pengetahuan tentang konsumsi makanan bergizi khususnya bahan makanan sumber zat besi. Hal ini terjadi karena pada kelompok intervensi edukasi kelompok sebaya lebih menekankan metode diskusi, simulasi, dan praktek langsung. Informasi melalui panca indera hanya dapat diserap $20 \%$ sehingga tindakan atau ketrampilan melalui simulasi, demonstrasi, dan praktek sangat diperlukan dalam metode pembelajaran.[11] [12] Sejalan dengan Rapiasih, dkk, bahwa penginderaan mempengaruhi penyerapan informasi, jika melibatkan telinga, mata, yang disertai diskusi, simulasi, latihan dan praktik, maka informasi akan terserap 90\%.[13]

Kelompok sebaya yang dalam hal ini adalah karang taruna sebagai salah satu media atau sarana untuk saling berdiskusi, bertukar pikiran, penyuluhan atau edukasi kesehatan terkait masalah yang dihadapi, sehingga melalui kelompok dapat dicapai keberhasilan, kepuasan dan sekaligus kehidupan yang lebih efektif. Kelompok sebaya bertujuan saling membantu menyelesaikan masalah anggotanya dan adanya proses pembelajaran dan pendidikan, sehingga berorientasi pada kegiatan kognitif.[14] Kelompok sebaya juga merupakan salah satu wujud dukungan sosial yang diberikan kepada anggotanya dengan tujuan promosi kesehatan.[15] Hal ini sejalan dengan intervensi pada penelitian ini. Intervensi edukasi pada penelitian ini dilakukan oleh duta gizi remaja bersama tim peneliti, melibatkan Puskesmas dengan beberapa metode penyampaian materi yaitu ceramah, diskusi, simulasi, dan praktik.

Terdapat perubahan sikap ke arah positif sebelum dan setelah intervensi baik pada kelompok perlakuan maupun kelompok kontrol. Hal itu dibuktikan dengan nilai t minus (-), artinya nilai sikap setelah intervensi lebih tinggi dibandingkan sebelum intervensi. Nilai sikap sebelum dan setelah intervensi pada kelompok perlakuan berubah positif secara signifikan dengan nilai $\mathrm{p}=0,002(\mathrm{p}<0,05)$. Nilai sikap sebelum dan setelah intervensi pada kelompok kontrol berubah secara positif tetapi tidak signifikan dengan $p=0,46(p>0,05)$. Hal ini menunjukkan ada pengaruh signifikan terhadap sikap remaja tentang pencegahan anemia gizi besi melalui edukasi kelompok sebaya dibanding remaja yang tidak mengikuti kegiatan edukasi kelompok sebaya.

Peningkatan sikap yang lebih tinggi pada kelompok perlakuan dalam pencegahan anemia gizi besi terjadi karena dalam kelompok sebaya terjadi interaksi yang dinamis antar anggota kelompok, saling memberikan dukungan informasi, saling membimbing, dan memberi penghargaan satu sama lain, sehingga tercipta kesadaran serta niat berperilaku sesuai dengan kelompoknya. Sejalan dengan Pender, et al. dan Bomar, bahwa bentuk transaksi interpersonal dalam kelompok sebaya adalah bantuan (informasi, materi atau jasa, materi), dan pernyataan (pengakuan dan umpan balik konstruktif).[14] [16] 


\subsection{Perbedaan pengetahuan, sikap dalam pencegahan anemia gizi besi antara kelompok perlakuan dan kontrol}

Hasil analisis perbedaan pengetahuan, sikap dalam pencegahan anemia gizi besi kelompok perlakuan dan kontrol disajikan dalam Tabel 4.

Tabel 4. Analisis Perbedaan Rata-Rata Pengetahuan, Sikap Remaja dalam Pencegahan Anemia Gizi Besi antara Kelompok Perlakuan dan Kontrol

\begin{tabular}{lcccc}
\hline \multicolumn{1}{c}{ Variabel } & Mean & SD & Nilai t & Nilai p \\
\hline Perubahan Pengetahuan & 10,50 & 9,70 & - & 0,001 \\
Kelompok Perlakuan & 4,50 & 13,4 & & \\
Kelompok Kontrol & & & & \\
\hline Perubahan Sikap & 3,20 & 6,29 & 1,527 & 0,131 \\
$\quad$ Kelompok Perlakuan & 0,88 & 7,64 & & \\
$\quad$ Kelompok Kontrol & & & \\
\hline
\end{tabular}

Hasil analisis bivariat pada Tabel 4., menunjukkan bahwa terdapat perbedaan nilai pengetahuan yang signifikan antara kelompok perlakuan dengan kelompok kontrol dengan $p=0,001(p<0,05)$. Sedangkan untuk perbedaan nilai sikap diperoleh hasil yang tidak signifikan antara kelompok perlakuan dengan kelompok kontrol dengan nilai $\mathrm{p}=0,131(\mathrm{p}>0,05)$.

Pendidikan kesehatan dalam jangka pendek hanya dapat menghasilkan perubahan atau peningkatan pengetahuan. Sedangkan untuk jangka menengah dari pendidikan ialah perubahan perilaku.[17] Peningkatan pengetahuan tentang anemia pada remaja setelah diberikan edukasi, diharapkan dapat mengubah perilaku dalam pencegahan anemia gizi besi pada diri dan lingkungannya. Interaksi dalam kelompok sebaya dapat mempengaruhi perilaku satu sama lain, sehingga dapat tumbuh saling membantu, menghargai, serta bertanggng jawab terhadap aturan yang disepakati bersama. Diperkuat oleh Azwar yang menyatakan bahwa salah satu faktor yang mempengaruhi pembentukan sikap adalah pengaruh orang lain yang dianggap penting, dalam hal ini duta gizi remaja dalam kelompok sebayanya.[6]

Lingkungan sosial dan sebaya memberikan pengaruh kuat pada remaja terhadap pengetahuan gizi, sikap dalam pencegahan anemia gizi besi, serta terjadi proses dalam kelompok yang berorientasi pada perilaku dan kognitif.[14]

\section{Kesimpulan}

Intervensi edukasi kelompok sebaya meningkatkan pengetahuan secara signifikan. Nilai sikap sebelum dan setelah intervensi pada kelompok perlakuan berubah positif secara signifikan sedangkan pada kelompok kontrol nilai sikap berubah secara positif tetapi tidak signifikan. Berdasar hasil tersebut perlu optimalisasi kelompok sebaya yang sudah ada di masyarakat, mengintegrasikan upaya promotif dan preventif anemia gizi besi ke dalam programnya. 


\section{Referensi}

[1]. Depkes RI. (2006). Profil kesehatan Indonesia. Jakarta: Depkes RI.

[2]. Riskesdas (2013). Badan Penelitian dan Pengembangan Kesehatan. 2013. Riset Kesehatan Dasar Kementerian Kesehatan Republik Indonesia. Jakarta

[3]. Riskesdas (2018). Badan Penelitian dan Pengembangan Kesehatan. 2018. Riset Kesehatan Dasar Kementerian Kesehatan Republik Indonesia. Jakarta

[4]. Kemenkes RI. Profil Kesehatan Indonesia. (2014)

[5]. Azwar, S. (2005). Sikap manusia teori dan pengukurannya. Edisi ke-2. Yogyakarta: Pustaka Pelajar

[6]. Depkes RI. (2005). Perkembangan program gizi masyarakat. Direktorat Gizi MasyarakatDepkesRI. http://www.gizi.net/busung-lapar/Penanggulangan\%20 Gizi\%20menkes1Juni\%202005.doc, diperoleh 5 Agustus 2020

[7]. Waryana. (2016). Promosi Kesehatan, Penyuluhan, dan Pemberdayaan Masyarakat. Yogyakarta: Nuha Medika

[8]. Sulistyowati, A.M., dkk. (2019). Pengaruh Penyuluhan Dan Media Poster Tentang Anemia Terhadap Tingkat Pengetahuan Dan Sikap Pada Santriwati (Studi Di Pondok Pesantren Al-Bisyri Kota Semarang). Jurnal Kesehatan Masyarakat (e-Journal). Vol.7. No 4

[9]. Sefaya, K. T., Nugraheni, S. A. \& Rahayuning, D. (2017). Pengaruh Pendidikan Gizi Terhadap Pengetahuan Gizi dan Tingkat Kecukupan Gizi Terkait Pencegahan Anemia Remaja (Studi Pada Siswa Kelas XI SMA Teuku Umar Semarang). J. Kesehatan Masyarakat.5, 272-282.

[10]. Rohim, A.N., Zulaekah, S., Kusumawati, Y.,. (2016). Perbedaan Pengetahuan Anemia Pada Remaja Putri Setelah Diberi Pendidikan Dengan Metode Ceramah Tanpa Media Dan Ceramah Dengan Media Buku Cerita. Journal Kesehatan. ISSN 1979-7621, Vol. 1, No. 2

[11]. Suciati. (2005). Taksonomi tujuan instruksional. Jakarta: PAU-PPAI UT Dirjen Dikti Depdiknas.

[12]. Bastable, S.B. (2002). Nurse as educator: principles of teaching and learning. Alih bahasa Gerda Wulandari dan Gianto Widiyanto.Jakarta: EGC.

[13]. Rapiasih, N. W., Prawiningdyah, Y., Lestari LA., (2010). Pelatihan Hygiene Sanitasi dan Poster Berpengaruh terhadap Pengetahuan, Perilaku Penjamah Makanan dan Kelaikan Hygiene Sanitasi di Instalasi Gizi RSUP Sanglah Denpasar. Jurnal Gizi Klinik Indonesia, Vol. 7, No. 2: 64-73.

[14]. Pender, N.J., Murdaugh, C.L., \& Parsons, M.A. (2002). Health promotion in nursing practice. (4th ed.). New Jersey: Pearson Education, Inc.

[15]. O'Connor-Fleming, M.L., \& Parker, E. (2001). Health promotion principles and practice in the Australian context. ( $2^{\text {nd }}$ ed.). Australia: Allen \& Unwin.

[16]. Bomar, P.J. (2004). Promoting health in families: Applying family research $\mathcal{E}$ theory to nursing practice. ( $3^{\text {rd }}$ ed.). Philadelphia: Sounders.

[17]. Notoatmodjo, S., 2007, Promosi Kesehatan dan Ilmu Perilaku, Jakarta, Rineka Cipta 